\title{
The Effect of Work Discipline, Remuneration and Leadership Style on Employee Performance in PT. DWI Karya Prima (PT DKP)
}

\author{
Krisantika Amiani ${ }^{1}$, Charles Bohlen Purba ${ }^{2}$ \\ ${ }^{1}$ Master of Management, Mercubuana University, Jakarta, Indonesia \\ ${ }^{2}$ Lecturer of Postgraduate, Mercubuana University, Jakarta, Indonesia
}

\begin{abstract}
This study aims to analyze the effect of Work Discipline, Remuneration, and leadership style in PT DKP Tangerang on employee performance. This study uses a quantitative approach and was taken during September 2019 - June 2020. The population studied was 60 employees of PT DKP Tangerang. The sampling method used was saturated sampling method with nonprobability sampling techniques. The method of analysis used in this study is multiple linear regression with the help of the SPSS ( Statistical Product For Service Solution) program) Version 25.0. The results showed that the variables of work discipline, remuneration, and leadership style partially and simultaneously had a positive and significant influence on employee performance. Based on the research results, it is suggested that the company should further improve work discipline by acting more firmly on disciplinary violations, changing the remuneration system to be fairer and changing the appropriate leadership style.
\end{abstract}

Keywords:- Work Discipline, Remuneration, Work Stress, Employee Performance.

\section{INTRODUCTION}

The era of globalization which is increasingly advanced and developing requires a company to be able to adjust itself so as not to experience a failure in the face of increasingly fierce competition. Currently, infrastructure development in Indonesia is very developing. Many construction-related companies are indispensable for the achievement of this infrastructure development. This is an opportunity for sub-contracting companies to get a share in working on the infrastructure development project. The infrastructure development project is an opportunity for sub-contractor entrepreneurs to participate in it, one of which is PT DKP.

PT DKP is a company engaged in manufacturing and services for infrastructure. The company PT DKP provides both tools, spare parts or services that are used to support infrastructure development. This opportunity is used by PT DKP to further develop its products and services in the market. In order to achieve its goals, PT DKP must be able to provide services and create strong and good human resources (HR) to maintain the quality of products and services offered in the market. Human resources are an asset for the company in realizing its goals and are the prime mover in achieving the company's vision and mission effectively and efficiently.

In carrying out company activities, employees are required to carry out their duties and obligations appropriately in accordance with the applicable regulations at PT DKP, so that PT DKP can meet the needs of customers who order. However, based on performance data, especially in the last 3 years, there has been a tendency to decrease employee performance.

\begin{tabular}{|c|c|c|c|c|c|c|c|c|}
\hline \multirow{2}{*}{ Year } & $\mathrm{A}$ & \multirow{2}{*}{$\%$} & $\mathrm{~B}$ & \multirow{2}{*}{$\%$} & $\mathrm{C}$ & \multirow{2}{*}{$\%$} & \multirow{2}{*}{ Presentase } & $\begin{array}{c}\text { Total } \\
\text { Employee }\end{array}$ \\
\cline { 9 - 10 } & & & & & & & 60 \\
\hline 2016 & 19 & $31,7 \%$ & 21 & $35,0 \%$ & 20 & $33,3 \%$ & $100,0 \%$ & 60 \\
\hline 2017 & 16 & $26,7 \%$ & 23 & $38,3 \%$ & 21 & $35,0 \%$ & $100,0 \%$ & 60 \\
\hline 2018 & 15 & $25,0 \%$ & 22 & $36,7 \%$ & 23 & $38,3 \%$ & $100,0 \%$ & 60 \\
\hline
\end{tabular}

Table 1: - Performance Assessment of PT. DKP Source: Human Resources Division of PT. Dwi Karya Prima, processed in January 2019

Based on secondary data above, the performance value of PT DKP has continued to decline in the last 3 (three) years. In table 1.1 it can be seen that there was an increase in the acquisition of "Enough" performance values in 2016 of $38.3 \%$, in 2017 it had increased by $1.7 \%$ and in 2018 it had increased again by $3.3 \%$. As well as some employees who have received a "Good" score has decreased from each year. In 2016, it was $31.7 \%$, decreased in 2017 by $5 \%$ and decreased again in 2018 by $1.7 \%$.

\section{THEORETICAL REVIEW}

\section{A. Work Discipline}

Meanwhile, according to Rivai (2014: 825) work discipline is a tool used by managers to communicate with employees so that they are willing to change a behavior and as an effort to increase one's awareness and willingness to obey all company regulations and applicable social norms. According to Sutrisno (2013: 86) states that discipline is the attitude of a person's willingness and willingness to obey and obey the prevailing regulatory norms around him.

\section{B. Remuneration}

Su'udin \& Gorda, (2016: 13) suggest that remuneration is a service fee or remuneration provided by a company to workers. This is because the workforce concerned has contributed energy and thoughts for the progress of the company in order to achieve predetermined 
goals. According to Mondy and Noe (1993) in Marwansyah (2010: 269 ), states that remuneration is a form of reward received by an employee for their contribution to the organization. Basically, remuneration is a tool to realize the vision and mission of an organization because remuneration itself aims to attract capable and experienced employees, retain quality employees, motivate employees to work effectively, motivate the formation of positive behavior, and become a tool to control expenses. where these are factors that can help achieve the organization's vision and mission.

\section{Leadership Style}

According Nugroho (2019: 345) definition of the style of leadership is the ability to direct, influence, encourage and control other people or subordinates to bias do something on his consciousness and voluntary work in achieving a certain goal. Meanwhile, according to Rivai (2014: 42) states that leadership style is a set of features used by leaders to influence subordinates so that organizational goals are achieved or it can also be said that leadership style is a pattern of behavior and strategies that are preferred and often applied by leaders.

\section{Performance}

According to Rivai and Sagala (2014 : 548) say that performance is the real behavior of employees as work performance that is generated in accordance with their role in the company. Meanwhile, according to Mangkunegara (2014: 77) performance is the result of work in quality and quantity by an employee in carrying out his duties according to the responsibilities given. In addition, according to Moeheriono (2012: 25 ) performance is a description of the level of achievement of the implementation of an activity program or policy in realizing the goals, objectives, vision and mission of the organization as outlined in the organization's strategic planning.

\section{E. Framework}

Work discipline, remuneration and leadership style are variables that can affect employee performance. So that the positive dapanya can affect employee performance and of course will have an impact on the progress of the company. Such as the results of the journal Azahraty (2018), which explains that leadership style and work discipline have a positive effect on employee performance, and the results of the journal Teja (2017), which explain that remuneration has a positive effect on employee performance.

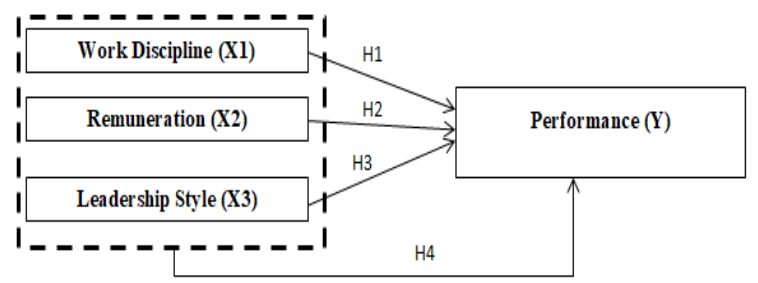

Fig 1:- Conceptual Framework

\section{F. Hypothesis}

The hypothesis is a temporary answer or provisional assumption to the research problem that has been formulated based on the theories used and is related to support the discussion of variables. The hypotheses put forward include:

$>\mathrm{H} 1$ : There is a positive and significant influence between work discipline on employees performance of PT DKP.

$>\mathrm{H} 2$ : There is a positive and significant influence between remuneration on employees performance of PT DKP

$>\mathrm{H} 3:$ There is a positive and significant influence between leadership styles on employees performance of PT DKP

$>\mathrm{H} 4$ : There is a positive and significant influence between work discipline, remuneration and leadership style on employees performance of PT DKP

\section{METHODOLOGY}

\section{A. Type of Research}

The research design used an exploratory survey method with a causal approach. This causal approach is a method for seeing the relationship between variables to the object under study is cause and effect, so that in his research there are independent variables and there are dependent variables in them (Sakaran \& Bougie 2017: 112).

\section{B. Population and Sample}

The population studied by the researcher were 60 employees of PT DKP. Sampling in this study used the Cosensus technique. This sampling technique uses all samples. This is often done when the population is relatively small or the study makes generalizations with very few errors. Another term that is full sample is census (Sugiyono 2013 : 59). Therefore, the number of samples in this study is in accordance with the total population at PT. DKP as many as 60 people.

\section{Variable Measurement Scale}

In this study, the authors set a measurement scale, namely the Likert scale with ordinal type, in which the writer determines the answer range value himself. The Likert scale used is adjusted to the type of question used on the variable, with a score range of 1 to 5: 1 (Strongly disagree), 2 (disagree), 3 (Enough Agree), 4 (agree), 5 (strongly agree)

\section{Data Collection Techniques \\ Primary data collection and secondary data collection .}

\section{E. Data Analysis Techniques \\ Data analysis techniques d nature of this research using analysis of multiple linear regression (multiple regression analysis) IBM SPSS ( Statistical Product and Service Solutions ) version 25.0.}




\section{RESULTS AND DISCUSSION}

In the following, the researcher will provide a more compelling description of the respondent's description consisting of gender, age, work unit, last education and length of work of PT DKP employees. The characteristics of the researcher respondents describe the following:

\section{A. Descriptive Analysis of PT DKP}

Employee Characteristics

The results of the descriptive analysis of the characteristics of PT DKP employees are that the most gender of employees is male, namely 51 people or $85 \%$, the most age is 27-28 years with 24 people, the work unit of employees at PT DKP is the largest number of CNC operators, 14 people $23.3 \%$, education is mostly SMA / SMK / STM as many as 42 people or $70 \%$, and the most length of work is around 3-5 years, namely 30 people or $(50 \%)$.

\section{B. Validity Test Results}

\begin{tabular}{|c|c|c|c|c|}
\hline Variable & $\begin{array}{c}\text { Number of } \\
\text { Items }\end{array}$ & $\begin{array}{c}\text { R- } \\
\text { Count }\end{array}$ & $\begin{array}{c}\text { R- } \\
\text { Table }\end{array}$ & Desc. \\
\hline $\begin{array}{c}\text { Work discipline } \\
\text { (X1) }\end{array}$ & 12 & $\begin{array}{c}0.260- \\
0.497\end{array}$ & 0.254 & Valid \\
\hline $\begin{array}{c}\text { Remuneration } \\
\text { (X2) }\end{array}$ & 34 & $\begin{array}{c}0.255- \\
0.824\end{array}$ & 0.254 & Valid \\
\hline $\begin{array}{c}\text { Leadership Style } \\
\text { (X3) }\end{array}$ & 12 & $\begin{array}{c}0.503- \\
0.749\end{array}$ & 0.254 & Valid \\
\hline Performance (Y) & 22 & $\begin{array}{c}0.258- \\
0.644\end{array}$ & 0.254 & Valid \\
\hline
\end{tabular}

Table 2: - Validity Test Results

Source: Results of analysis using SPSS 25.0 (2020)

Validity states accuracy or preciseness. The higher the accuracy of the data that occurs on the object of research with the data reported by the researcher, the higher the validity of the data. The test was carried out using the Pearson Product Moment Correlation, if $r$ count $>r$ table it means valid. If $\mathrm{r}$ count $>\mathrm{r}$ table with $\mathrm{d} f=\mathrm{n}-2(58)$ dida patkan value of 0,254 with $\alpha=0.05$, the correlation coefficient was significant.

C. Reliability Test Results

\begin{tabular}{|c|c|c|c|}
\hline Variable & $\begin{array}{c}\text { Number of } \\
\text { Items }\end{array}$ & $\begin{array}{c}\text { Cronbach's } \\
\text { Alpha }\end{array}$ & Desc. \\
\hline $\begin{array}{c}\text { Work discipline } \\
(\mathrm{X} 1)\end{array}$ & 12 & 0.752 & Reliable \\
\hline $\begin{array}{c}\text { Remuneration } \\
(\mathrm{X} 2)\end{array}$ & 34 & 0.631 & Reliable \\
\hline $\begin{array}{c}\text { Leadership } \\
\text { Style (X3) }\end{array}$ & 12 & 0.878 & Reliable \\
\hline Performance (Y) & 22 & 0.711 & Reliable \\
\hline
\end{tabular}

Table 3: - Reliability Test Results

Source: Results of analysis using SPSS 25.0 (2020)
Reliability relates to the consistency and predictability test of a measuring instrument. The test is carried out by comparing the Cronbach Alpha number where the minimum Cronbach Alpha value is 0.6 or $\geq 0.6$. If the value generated da $r$ i SPSS calculation result greater than 0.6 then the questionnaire is reliable, whereas otherwise it is not reliable.

\section{Normality Test Results}

One-Sample Kolmogorov-Smirnov Test

\begin{tabular}{|c|c|c|}
\hline & & $\begin{array}{l}\text { Unstandardize } \\
\text { d Residual }\end{array}$ \\
\hline \multicolumn{2}{|l|}{$\mathrm{N}$} & 60 \\
\hline \multirow[t]{2}{*}{ Normal Parameters ${ }^{a, b}$} & Mean & 0,0000000 \\
\hline & Std. Deviation & 6,41139058 \\
\hline \multirow[t]{3}{*}{ Most Extreme Differences } & Absolute & 0,053 \\
\hline & Positive & 0,039 \\
\hline & Negative & $-0,023$ \\
\hline \multicolumn{2}{|l|}{ Test Statistic } & 0,053 \\
\hline \multicolumn{2}{|l|}{ Asymp. Sig. (2-tailed) } & $200^{\circ}$ \\
\hline \multicolumn{3}{|l|}{ a. Test distribution is Normal. } \\
\hline \multicolumn{3}{|l|}{ b. Calculated from data. } \\
\hline \multicolumn{3}{|c|}{ c. Lilliefors Significance Correction. } \\
\hline
\end{tabular}

Table 4: - Results of the Kolmogorov-Smirnov Test Source: Results of analysis using SPSS 25.0 (2020)

The results of the normality test of this study are shown in the One-Sample Kolmogorov-Smirnov Test table above. From the table above it can be seen that the Asymp. Sig (2-tailed) is $0.20(20 \%)$ which means that it is greater than $0.05 \quad(5 \%)$ as a condition of normally distributed research data. Thus Ho is accepted (0.20> 0.05) and the conclusions drawn are normal distribution data.

\section{E. Multicollinearity Test Results}

The multicollinearity test results using SPSS 25.0 indicate that the VIF value for each independent variable is less than 10 and the tolerance value is more than 0.1 . Thus it can be concluded that this regression model is free from multicollinearity .

\section{F. Heteroscedasticity Test}

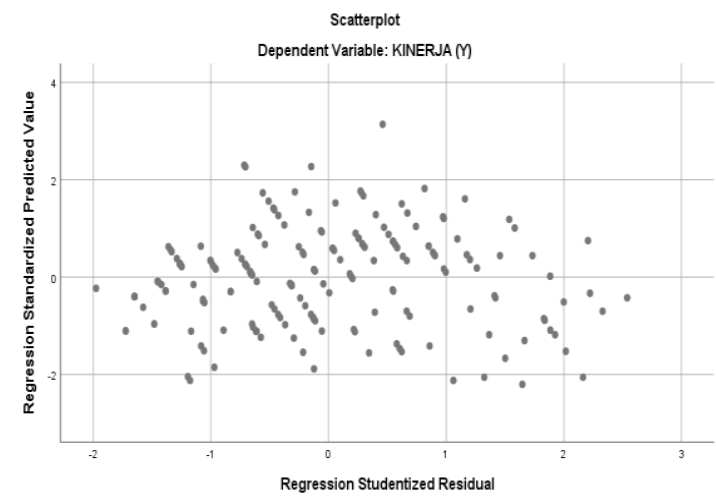

Fig 2:- Heteroscedasticity test results Source: Results of analysis using SPSS 25.0 (2020) 
The results of heteroscedasticity testing are shown in the figure above. From the scatterplot test results, it can be seen that the dots spread with an unclear pattern above and below the number 0 on the $\mathrm{Y}$ axis. These results indicate that there is no Hetheroscedasticity problem in this research model.

\section{G. Multiple Linear Regression Analysis}

The use of multiple linear regression because this study uses more than one independent variable, including the variable Work Discipline (X1), Remuneration (X2), Leadership Style (X3), to determine the effect on the dependent variable Employee Performance variable (Y) PT DKP . Data processing using SPSS ( Statistical Package for Social Sciences ) 25.0.

\section{Simultaneous Significance Test Results (Test f)}

Based on data processing using SPSS (Statistical Package for Social Sciences ) 25.0, the results obtained the value of F count $=41.244$ and a Sig value of 0.003 . While the $F$ table value with df (3.56) $=2.77$. Thus $\mathrm{H}_{0}$ is rejected, thus the variable Work Discipline (X1), Remuneration (X2), Leadership Style (X3) together have a significant effect on the Employee Performance variable (Y).

\section{T test result (partial)}

According to Ghazali ( 2016 ), to calculate the t-table the provisions $\mathrm{df}=\mathrm{nk}=60-4=56)=2.00$ at the level of significant $(\alpha)$ of $5 \%$ ( error rate $5 \%$ or 0,05 ) or the level of confidence $95 \%$ or 0,95 , so a sovereign, when the error rate variable more than $5 \%$ means that the variable was not significant. The way of making decisions is:

- If probability / significance $>0,05$ or $\mathrm{t}$ count $<\mathrm{t}$ table, Ho is accepted.

- If probability / significance $<0,05$ or $\mathrm{t}$ count $>\mathrm{t}$ table, Ho is rejected.

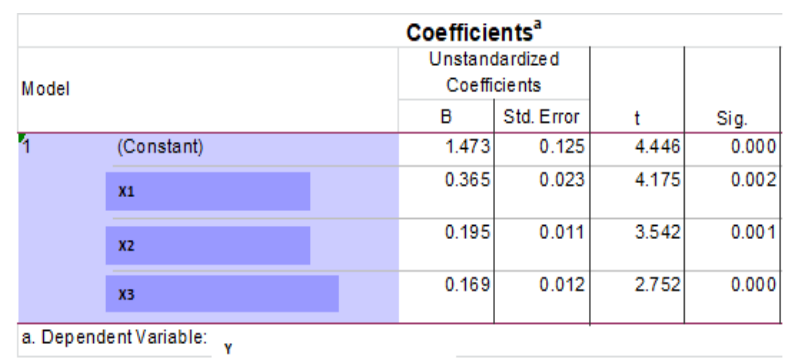

Table 5: - Multiple Regression Test Results

Source: Results of analysis using SPSS 25.0 (2020)

Based on the table above, the regression equation model is obtained as follows:

$\mathrm{Y}=1,473+0,365 \mathrm{X}_{1}+0,195 \mathrm{X}_{2}+0,169 \mathrm{X}_{3}+e$

The meaning

- The constant is 1.473 and positive means that if the variable Work Discipline (X1), Remuneration (X2), Leadership Style (X3) is considered non-existent or equal to 0 , then the employee performance value (Y) is 1.473 . A positive coefficient indicates a positive relationship between constants and Employee
Performance (Y). A constant value of $0.000<0.005$, indicating a significant constant effect on employee performance $(\mathrm{Y})$.

- There is an effect of Work Discipline (X1) on Performance (Y) partially. The table above shows that the relationship between Work Discipline (X1) and Performance $(\mathrm{Y})$ is significant with a $\mathrm{t}$-count of 4.175 $(\mathrm{t}$-count $>\mathrm{t}$-table $(\mathrm{df}=56)=2.00)$ and the sig value. $=$ 0.002 . The coefficient value is positive, namely 0,365 which indicates that the direction of the relationship between Work Discipline (X1) and Performance (Y) is positive at $36.5 \%$. Thus the $\mathrm{H} 1$ hypothesis in this study which states that "Work Discipline (X1) has a significant effect on performance $(\mathrm{Y})^{\prime \prime}$ is accepted.

- There is an effect of Remuneration (X2) on Performance (Y) partially. The table above shows that the relationship between Remuneration (X2) and Performance (Y) is significant with a t-count of 3.542 $(\mathrm{t}$-count $>\mathrm{t}$-table $(\mathrm{df}=56)=2.00)$ and the sig value. $=$ 0.001 . The value of the coefficient is positive in the amount of 0.195 which indicates that the direction of the relationship between remuneration (X2) and Performance (Y) is positive at $19.5 \%$. Thus the hypothesis $\mathrm{H} 2$ in this study stated that that "Remuneration (X2) significantly affects the performance (Y)" acceptable.

- There is an effect of leadership style (X3) on performance $(\mathrm{Y})$ partially. The table above shows that the relationship between Leadership Style (X3) and Performance $(\mathrm{Y})$ is significant with a t-count of 2.752 $(\mathrm{t}$-count $>\mathrm{t}$-table $(\mathrm{df}=56)=2.00)$ and the sig value. $=$ 0.000 . The coefficient value is positive, namely 0,169 which indicates that the direction of the relationship between Leadership Style (X3) and Performance (Y) is positive at $16.9 \%$. Thus the hypothesis $\mathrm{H} 3$ in this study states that "Leadership Style (X3) has a significant effect on performance (Y)" is accepted.

\section{Result of Determination Coefficient Analysis (Adjusted $\left.R^{2}\right)$}

Based on data processing using SPSS ( Statistical Package for the Social Sciences ) 25.0 showed the value of $R^{2}$ amounting to $0,625(62.5 \%)$. This shows that the variation of the independent variables used in the model (Work Discipline, Remuneration and Leadership Style) is able to explain $62.5 \%$ of the variation in employee performance variables. While the rest is explained by other variables that are not included in this research model.

\section{H. Result of Inter-Dimensional Correlation Test}

Based on data processing using SPSS (Statistical Package for the Social Sciences ) 25.0 showed correlations among the most powerful dimension is

$>$ The greatest correlation value between dimensions in the Work Discipline variable (X1) on the Employee Performance Variable (Y) is the dimension $\mathrm{X} 1.3$ Obedience to rules and behavior with the Y1 
dimension Quality of work is 0.478 , and is included in the category of relationship level moderate.

$>$ The greatest correlation value between the dimensions in the Remuneration Variable (X2) on the Employee Performance Variable (Y) is the nonfinancial dimension X2.8 Opportunity for recognition with the Y8 Personal Qualities dimension is 0.642 (strong relationship category) and the financial dimension X2.2 Performance Allowance (incentives \& bonuses) with Y5 Cooperation, namely 0.528 (medium relationship category).

$>$ The greatest correlation value between dimensions in the Leadership Style variable (X3) on Employee Performance Variables (Y) is the X3.1 Idealized Influence dimension with the Y1 Quality of work dimension, namely 0.338 , and falls into the low level of relationship category.

\section{Discussion of Research Results}

\section{$>$ The Effect of Work Discipline on Employee Performance}

In this study, the obedience dimension to the rules and behavior of the work discipline variable has a strong influence on the Quality of work dimension on the employee performance variable. So it can be said that if PT DKP employees do work in accordance with their positions, duties and responsibilities and establish good relationships with other work units, then the quality of a person's work will also be better seen from the results of work completed in accordance with work standards.

\section{> The Effect of Remuneration on Employee Performance}

In this study, the financial dimension, namely performance allowances (incentives and bonuses) on the remuneration variable, has a strong influence on the coorperation dimension. So it can be said that if employees of PT DKP get a performance allowance (bonus \& intensive) it will increase these employees in contributing to every activity and establish good relationships with superiors and as well as with fellow employees. In this study also the non-financial dimension, namely the opportunity for recognition of the remuneration variable, has a strong influence on the personal qualities dimension . So it can be said that if employees of PT DKP are recognized by the company and their work environment for the work done, it can improve the quality of these employees to work better.

\section{The Effect of Leadership Style on Employee Performance}

In this study, the idealized influence dimension on leadership style variables has an influence on the quality of work dimension on employee performance variables. So it can be said that a leader has strong self-confidence, helps in the difficulties of his employees, has definite goals, and upholds moral values that can be role models for his subordinates so that his subordinates willingly follow and respect their superiors. If the role model followed by his subordinates is reliable, the quality of employee work in completing work will be better and completed according to company standards.

\section{The Effect of Work Discipline, Remuneration and Leadership Style on Employee Performance}

Work discipline, remuneration and leadership style together have an influence on the performance of PT DKP employees. To improve the performance of PT DKP employees, it can be done by increasing the work discipline of these employees through firmly implementing the applicable regulations in the company . In terms of remuneration, it can be increased through performance allowances in the form of bonuses and incentives as well as providing recognition of employee work results so that the employee's performance gets better. In addition, if viewed from the variable of leadership style, the idealized influence dimension (selfconfidence, helping employee difficulties, upholding morale, and having a clear vision) as a leader can be enhanced so that employees can become role models in doing work. These three things will improve the performance of PT DKP employees.

\section{CONCLUSIONS AND RECOMMENDATIONS}

\section{A. Conclusion}

Based on the results of research, data analysis, and discussion of the effect of work discipline, remuneration, and leadership style on employee performance at PT DKP, several conclusions can be drawn as follows:

$>$ Work discipline partially has a positive and significant effect on employee performance. This shows that good work discipline will increase employee performance.

$>$ Remuneration partially has a positive and significant effect on employee performance. This proves that the existing remuneration system in the company is a factor that can affect the level of employee work performance related to welfare and comfort at work.

$>$ Leadership style partially has a positive and significant effect on employee performance. This shows that with the right leadership style, employee performance will also increase.

$>$ D isiplin employment, remuneration and leadership styles together (simultaneously) have an influence on employee performance. With good work discipline, the right remuneration, and the right leadership style will lead to increased employee performance at PT DKP.

\section{B. Suggestions}

Based on the research results and conclusions above, the authors provide some suggestions for company leaders in order to improve employee performance, as well as suggestions for further research. The suggestions are as follows:

$>$ Work discipline is a positive influence on employee performance so it is important for company leaders to pay more attention to employee attendance and to be more assertive in following up on employee discipline.

$>$ Remuneration has a positive influence on employee performance, therefore with appropriate remuneration 
and in accordance with what the employee has produced, fair remuneration is given to each employee. Company leaders must look more at the work results of their employees so that they can provide performance benefits appropriately and accordingly.

The leadership style also has a positive influence on performance, therefore. Company leaders must use a leadership style that is appropriate for their employees so that all work is done right and according to company targets.

$>$ The company must design more properly and precisely to improve employee performance by paying attention to employee work discipline, remuneration, and the accuracy of leadership style. This is also supported by the results of research that has been conducted which argue that work discipline, remuneration, and leadership style together (simultaneously) have a significant influence on employee performance.

$>$ This study only uses work discipline, remuneration and leadership style variables which are considered to have a high influence on employee performance. But there are many other variables that can affect employee performance. Due to this, for further research, other independent variables can be used so that it can produce new conclusions related to employee performance. The use of a larger population can also be done to determine the effect on companies that are larger in scale.

\section{REFERENCES}

[1]. Azahraty. (2018). Pengaruh Gaya Kepemimpinan dan Disiplin Kerja Terhadap Kinerja Karyawan (Study Kasus Pada PT. Mitra Dana Putra Utama Banjarmasin). At-Tadbir: Jurnal Ilmiah Manajemen. Vol. 2. No. 1. hal. 24-34.

[2]. Ghozali, Imam. (2016). Aplikasi Analisis Multivariate dengan Program IBM SPSS 21. Semarang : UNDIP.

[3]. Ghozali, Imam. (2018). Aplikasi Analisis Multivariate dengan Program IBM SPSS 25 (Edisi 9). Semarang : UNDIP.

[4]. Gomes, Faustino Cardoso. (2010). Manajemen Sumber Daya Manusia. Penerbit Andi Offset, Yogyakarta.

[5]. Jyoti, Jevan., Manisha Dev. (2015). The Impact of Transformational Leadership on Employee Creativity : The Role of Learning Orientation. Journal of Asia Business Studies, Vol 9, No. 1, pp. 78-98.

[6]. Mangkunegara, Anwar Prabu \& Waris, Abdul. (2015). Efffect Training, Competence and Discipline on Employee Performance in Company (Case Study in PT. Asuransi Bangun Askrida). Procedia - Social and Behavioral Sciences. Vol. 211. pp 1240-1251.

[7]. Mangkunegara, Anwar P. (2014). Manajemen Sumber Daya Manusia Perusahan. Bandung: Remaja Rosdakarya.

[8]. Marwansyah. 2010. Manajemen Sumber Daya Manusia Edisi Kedua. Bandung: Alfabeta.

[9]. Moeheriono. (2012). Pengukuran Kinerja Berbasis Kinerja Edisi Revisi. Jakarta: PT. Raya Grafindo Persada.
[10]. Nugroho, Rosalendro Eddy. (2019). Pengaruh Gaya Kepemimpinan Transformasional Stress Kerja dan Budaya Organisasi Terhadap Kinerja Karyawan Kontrak Proyek. MIX: Jurnal Ilmiah Manajemen. Volume 9. No. 2. Juni 2019. hal. 341-354.

[11]. Parlindungan, Bernad Togu \& Purba, Charles Bohlen. (2018). Pengaruh kepemimpinan, kompensasi dan motivasi kerja terhadap kinerja karyawan di PT. Citra Makmur Sejahtera. Jurnal SWOT. Vol. VIII No.2. hal 306-317.

[12]. Putra, Desmil \& Haryanto. (2019). Effect Of Compensation, And Training on Work Discipline And its Impact On Employee Performance Of The Regional Recearch And Development Planning Agency In Dharmasraya Regency. Archives of Business Research. Vol. 7. No. 8. pp 66-75.

[13]. Rapsanjani, Anggi \& Johannes, Singmin. (2019). The Effect of Remuneration, Work Motivation and Job Satisfaction On Employees Performace. International Humanities and Applied Sciences Journal (IHSJ), Vol. 2, Issue 2. pp. 23-29.

[14]. Rivai, Veithzal. (2013). Manajemen Sumber Daya Manusia Untuk Perusahaan Dari Teori Ke Praktek. Rajagrafindo persada, Bandung.

[15]. Rivai Veithzal dan Ella Jauvani Sagala. (2014). Manajemen Sumber Daya Manusia Untuk Perusahaan : Dari Teori Ke Praktik. Edisi Kedua. Cetak ke Lima. Jakarta: PT. Rajafindo Persada.

[16]. Sekaran, Uma dan Bougie, Roger. (2017). Metode Penelitian untuk Bisnis Pendekatan PengembanganKeahlian. Edisi 6, Buku 1. Jakarta. Salemba Empat.

[17]. Sekaran, Uma dan Bougie, Roger. (2017). Metode Penelitian untuk Bisnis Pendekatan PengembanganKeahlian. Edisi 6, Buku 2. Jakarta. Salemba Empat.

[18]. Sugiyono. (2013). Metode Penelitian Pendidikan (Pendekatan Kuantitatif, Kualitatif, dan R\&D). Bandung : Alfabeta.

[19]. Sutrisno, Edy (2014). Manajemen Sumber Daya Manusia. Cetak Ke Enam. Jakarta: Kencana Pranada Media Group.

[20]. Su'udin, F. \& Gorda, O.S. (2016). Iklim Organisasi, Remunerasi, Mutasi Personal, Kepuasan Kerja Dan Kinerja Pegawai (Studi Pada KPP Pratama Badung Selatan). Jurnal Manajemen \& Bisnis. 13(3). Bulan Juni. hal. 11 - 31. ISSN : 1892-8486. Universitas Bandar Lampung.

[21]. Teja, Sri Gusti Bima Harya. (2017). Pengaruh Remunerasi dan Motivasi Kerja Terhadap Kinerja Karyawan (Studi Kasus Pada Kantor Pengawasan Pelayanan Bea dan Cukai Surakarta). DAYA SAING Jurnal Ekonomi Manajemen Sumber Daya. Vol. 19. No. 2. Desember 2017. hal. 109-118. 